Supporting Information for:

\title{
Sensitive and Selective Ratiometric Fluorescence Probes for Detection of Intracellular Endogenous Monoamine Oxidase A
}

Xiaofeng Wu, Lihong Li, Wen Shi, Qiuyu Gong, Xiaohua Li, and Huimin Ma*

National Laboratory for Molecular Sciences, Key Laboratory of Analytical Chemistry for Living Biosystems, Institute of Chemistry, Chinese Academy of Sciences, Beijing 100190, China. E-mail: mahm@iccas.ac.cn

\section{Synthesis of Starting Material NIOH}

As shown in Scheme S1, NIOH can be prepared from 4-bromo-1,8-naphthalic anhydride.

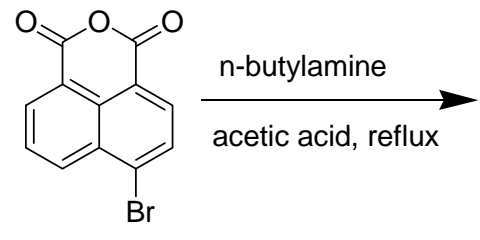<smiles>CCCCN1C(=O)c2cccc3c(Br)ccc(c23)C1=O</smiles>

$\mathrm{NI}-\mathrm{Br}$

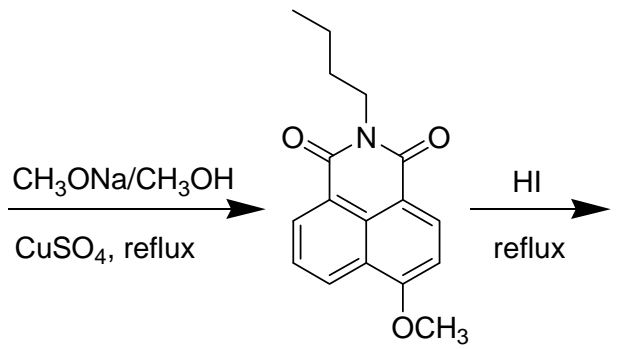

$\mathrm{NI}-\mathrm{OCH}_{3}$

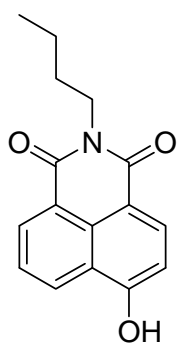

$\mathrm{NIOH}$

Scheme S1. Synthesis of NIOH.

NI-Br: Yield 74\%. ${ }^{1} \mathrm{H}-\mathrm{NMR}\left(400 \mathrm{MHz}, 298 \mathrm{~K}, \mathrm{CD}_{3} \mathrm{Cl}\right.$; Figure S1): $\delta 8.65$ (d, 1H, J=4 Hz), $8.56(\mathrm{~d}, 1 \mathrm{H}, \mathrm{J}=8 \mathrm{~Hz}), 8.41$ (d, 1H, J=8 Hz), 7.83 (t, 1H, J=8 Hz), 4.17 (t, 2H, J=8 Hz), 1.75-1.67 (m, 2H), 1.49-1.40 (m, 2H), 0.98 (t, 3H, J=8 Hz). ${ }^{13} \mathrm{C}-\mathrm{NMR}\left(100 \mathrm{MHz}, 298 \mathrm{~K}, \mathrm{CD}_{3} \mathrm{Cl}\right.$; Figure S2): $\delta$ 163.6, 163.6, 133.2, 132.0, 131.2, 131.1, 130.7, 130.2, 129.0, 128.1, 123.2, 122.4, 40.4, 30.2, 20.4, 13.8. HR-EI-TOF MS: $m / z$ calcd for NI-Br $\left(\mathrm{C}_{16} \mathrm{H}_{14} \mathrm{NO}_{2} \mathrm{Br}, \mathrm{M}^{+}\right), 331.0208$; found, 331.0213 .

NI-OCH 3 : Yield 81\%. ${ }^{1} \mathrm{H}-\mathrm{NMR}\left(400 \mathrm{MHz}, 298 \mathrm{~K}, \mathrm{CD}_{3} \mathrm{Cl}\right.$; Figure S3): $\delta 8.60(\mathrm{~d}, 1 \mathrm{H}, \mathrm{J}=5.4$ Hz), 8.56 (s, 1H), 8.53 (s, 1H), 7.69 (d, 1H, J=8 Hz), 7.04 (d, 1H, J=8 Hz), 4.17 (d, 2H, J=8 Hz), 4.12 (s, 3H), 1.75-1.68 (m, 2H), 1.50-1.42 (d, 2H), 0.98 (t, 3H, J=8 Hz). ${ }^{13} \mathrm{C}-\mathrm{NMR}(100 \mathrm{MHz}, 298$ $\mathrm{K}, \mathrm{CD}_{3} \mathrm{Cl}$; Figure S4): $\delta$ 164.5, 164.0, 160.8, 133.4, 131.5, 129.4, 128.5, 125.9, 123.5, 122.5, 115.1, 105.2, 56.2, 40.1, 30.3, 20.4, 13.9. HR-ESI-MS: $m / z$ calcd for NI-OCH${ }_{3}\left(\mathrm{C}_{17} \mathrm{H}_{18} \mathrm{NO}_{3}{ }^{+},[\mathrm{M}+\mathrm{H}]^{+}\right)$, 284.1281; found, 284.1282 . 
NIOH: Yield 71\%. ${ }^{1} \mathrm{H}-\mathrm{NMR}\left(400 \mathrm{MHz}, 298 \mathrm{~K}, \mathrm{DMSO}_{6}\right.$; Figure S5): $\delta 11.85$ (s, 1H), 8.55 (d, $1 \mathrm{H}, \mathrm{J}=8 \mathrm{~Hz}), 8.48(\mathrm{~d}, 1 \mathrm{H}, \mathrm{J}=4 \mathrm{~Hz}), 8.37$ (d, 1H), 7.76 (t, 1H, J=8 Hz), 7.17 (d, 1H, J=6 Hz), 4.02 (t, 2H, J=8 Hz), 1.63-1.56 (m, 2H), 1.39-1.29 (m, 2H), 0.92 (t, 3H, J=8 Hz). ${ }^{13} \mathrm{C}-\mathrm{NMR}(100 \mathrm{MHz}, 298$ K, DMSO-d 6 ; Figure S6): $\delta$ 164.1, 163.4, 160.7, 139.9, 131.5, 129.6, 129.3, 126.0, 122.8, 122.3, 113.1, 110.4, 39.5, 30.2, 20.3, 14.2. HR-ESI-MS: $m / z$ calcd for $\mathbf{N I O H ~}\left(\mathrm{C}_{16} \mathrm{H}_{14} \mathrm{NO}_{3}^{-},[\mathrm{M}-\mathrm{H}]^{-}\right)$, 268.0980; found, 268.0978 .

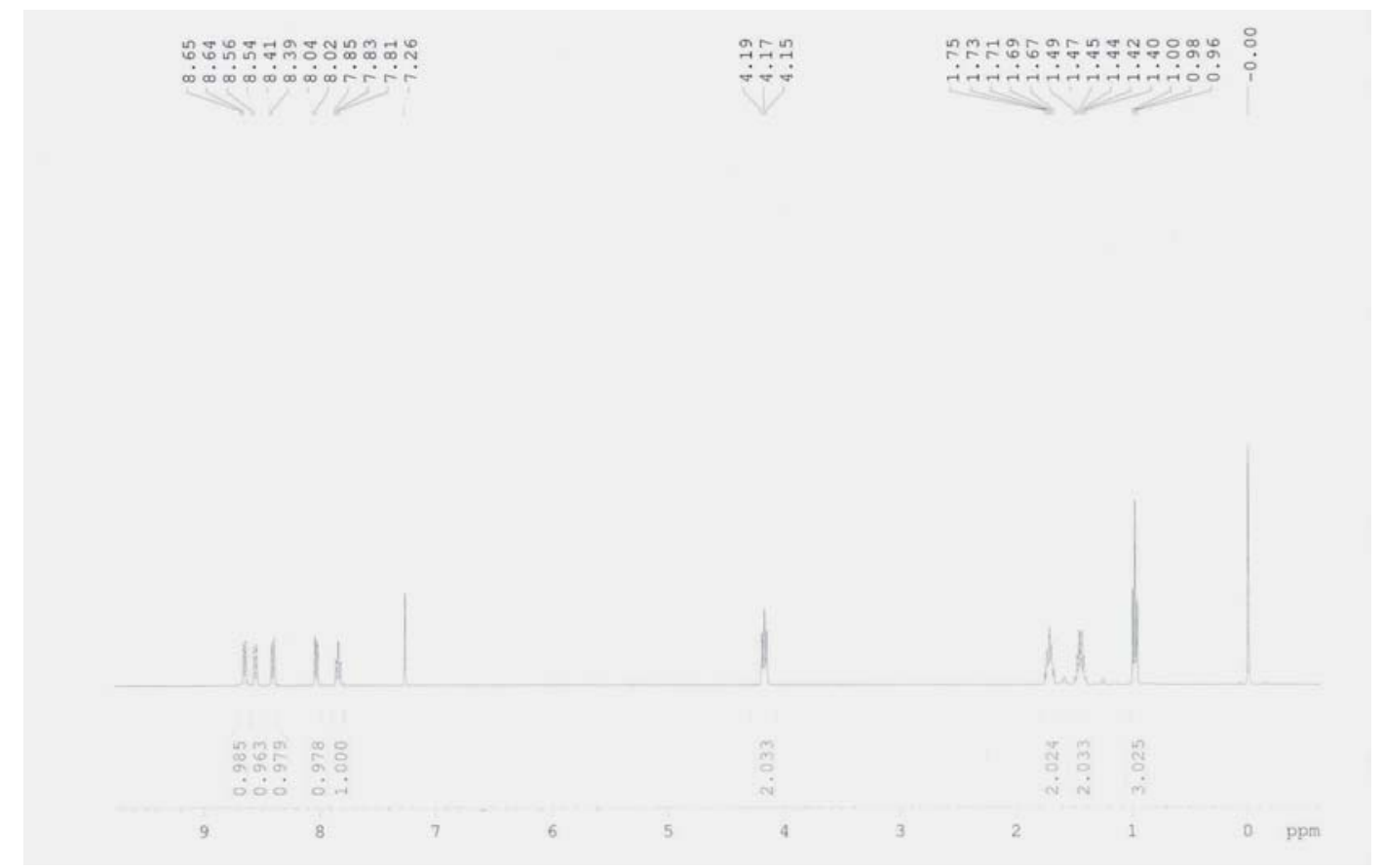

Figure S1. ${ }^{1} \mathrm{H}$ - NMR spectrum of NI-Br $\left(400 \mathrm{MHz}, 298 \mathrm{~K}, \mathrm{CDCl}_{3}\right)$.

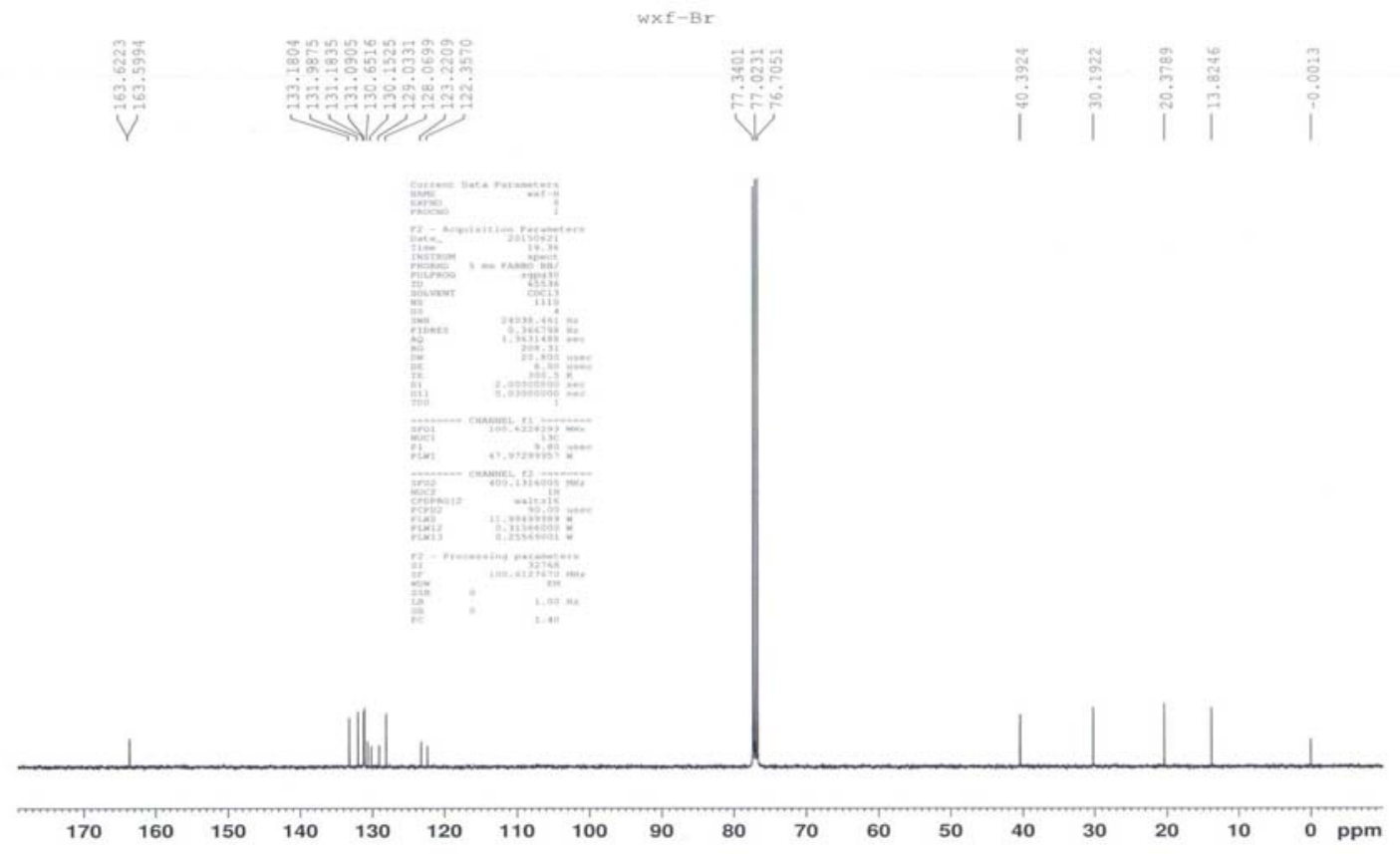

Figure S2. ${ }^{13} \mathrm{C}$ - NMR spectrum of $\mathbf{N I - B r}\left(100 \mathrm{MHz}, 298 \mathrm{~K}, \mathrm{CDCl}_{3}\right)$. 


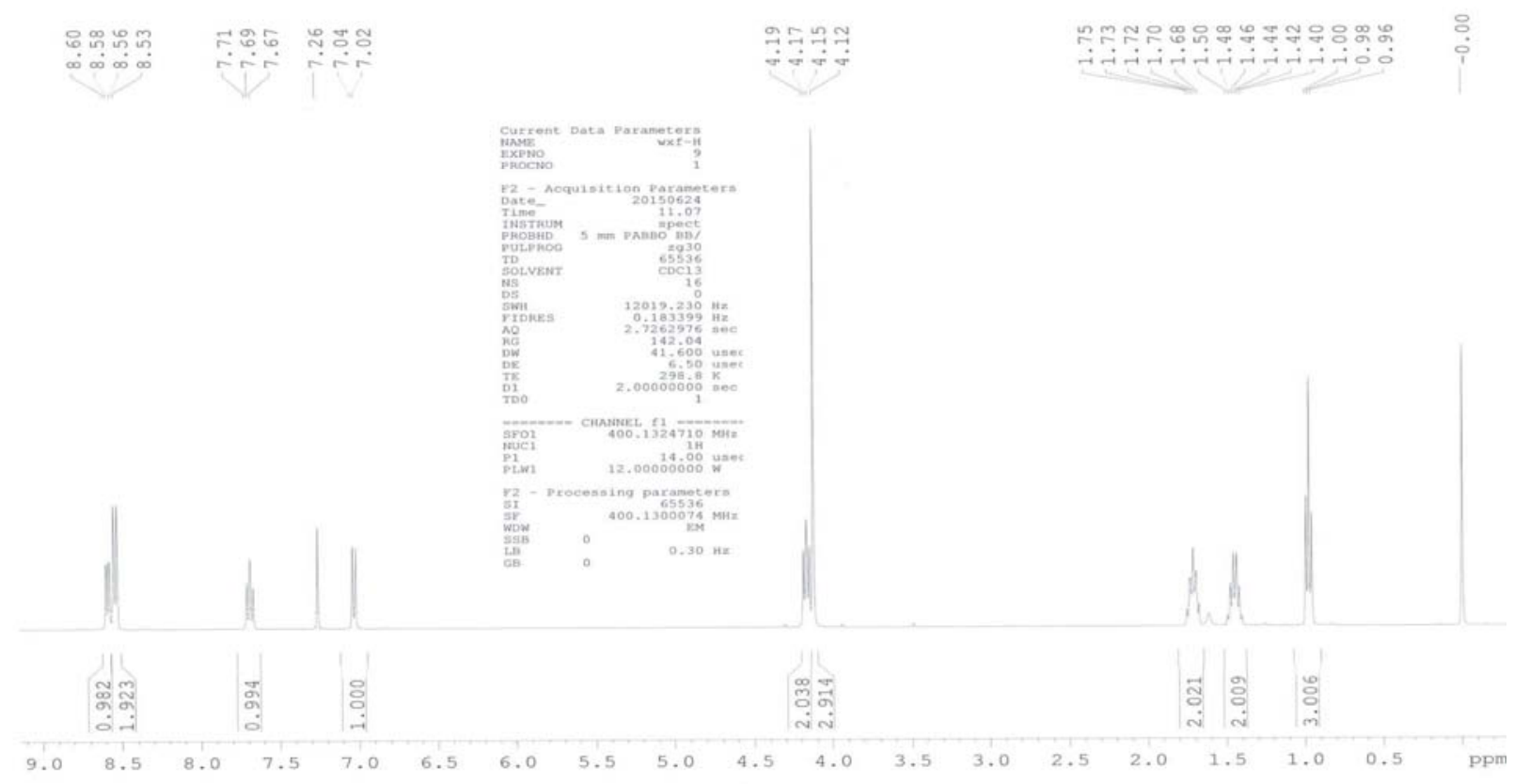

Figure S3. ${ }^{1} \mathrm{H}-\mathrm{NMR}$ spectrum of $\mathbf{N I - O C H}\left(400 \mathrm{MHz}, 298 \mathrm{~K}, \mathrm{CDCl}_{3}\right)$.

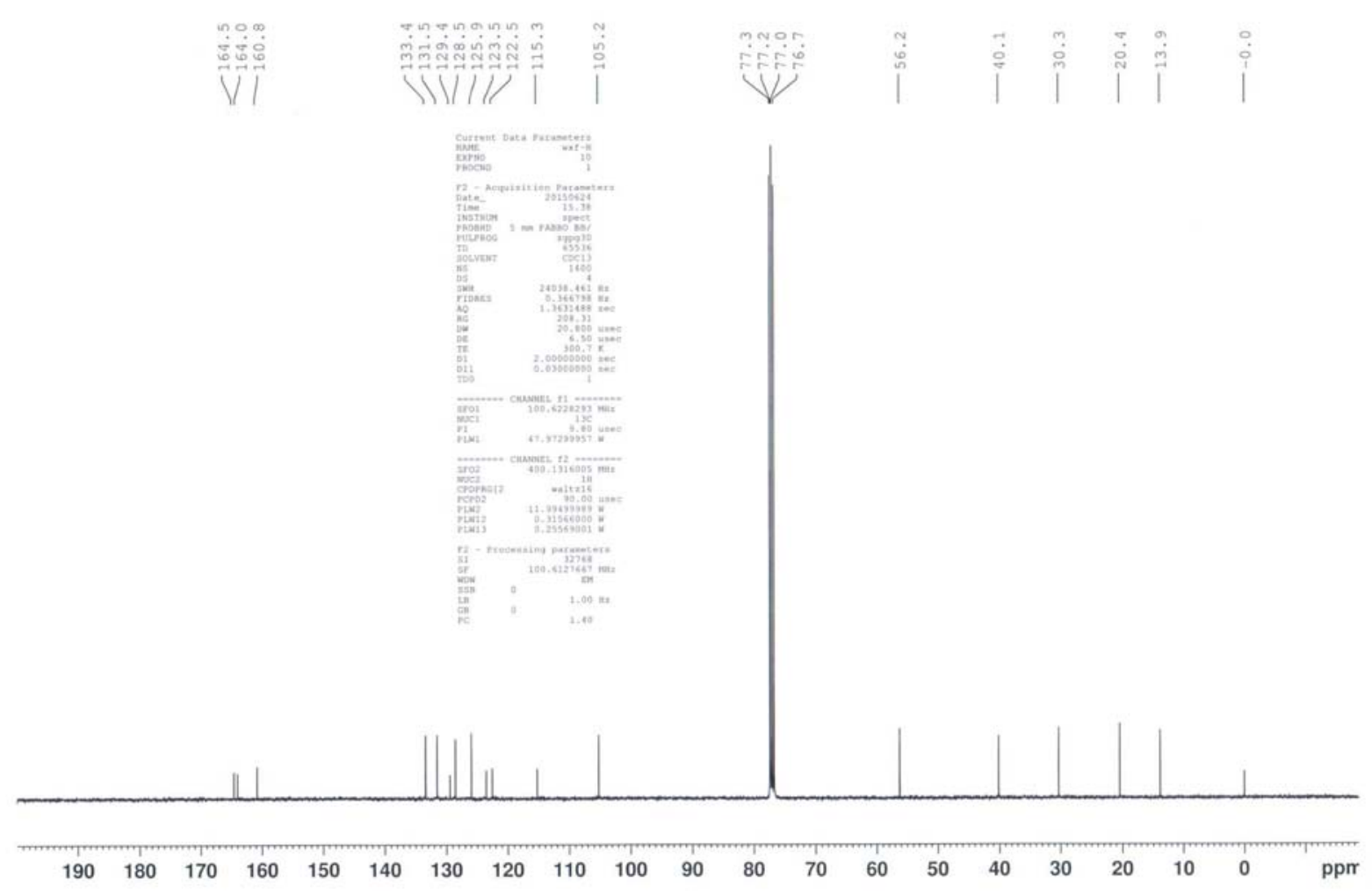

Figure S4. ${ }^{13} \mathrm{C}$ - NMR spectrum of NI-OCH $3\left(100 \mathrm{MHz}, 298 \mathrm{~K}, \mathrm{CDCl}_{3}\right)$. 


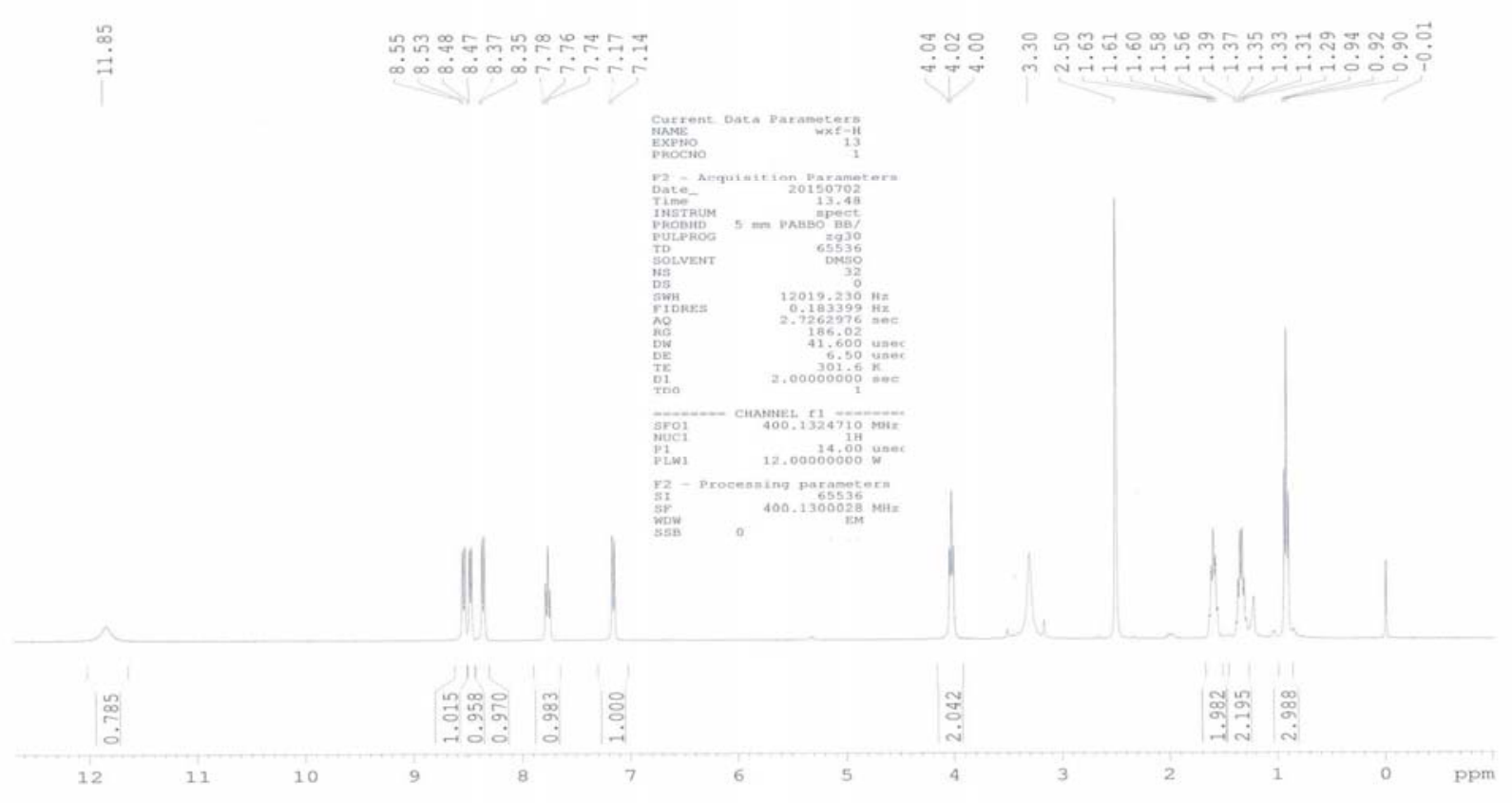

Figure S5. ${ }^{1} \mathrm{H}-\mathrm{NMR}$ spectrum of NIOH (400 MHz, $298 \mathrm{~K}$, DMSO-d 6 ).

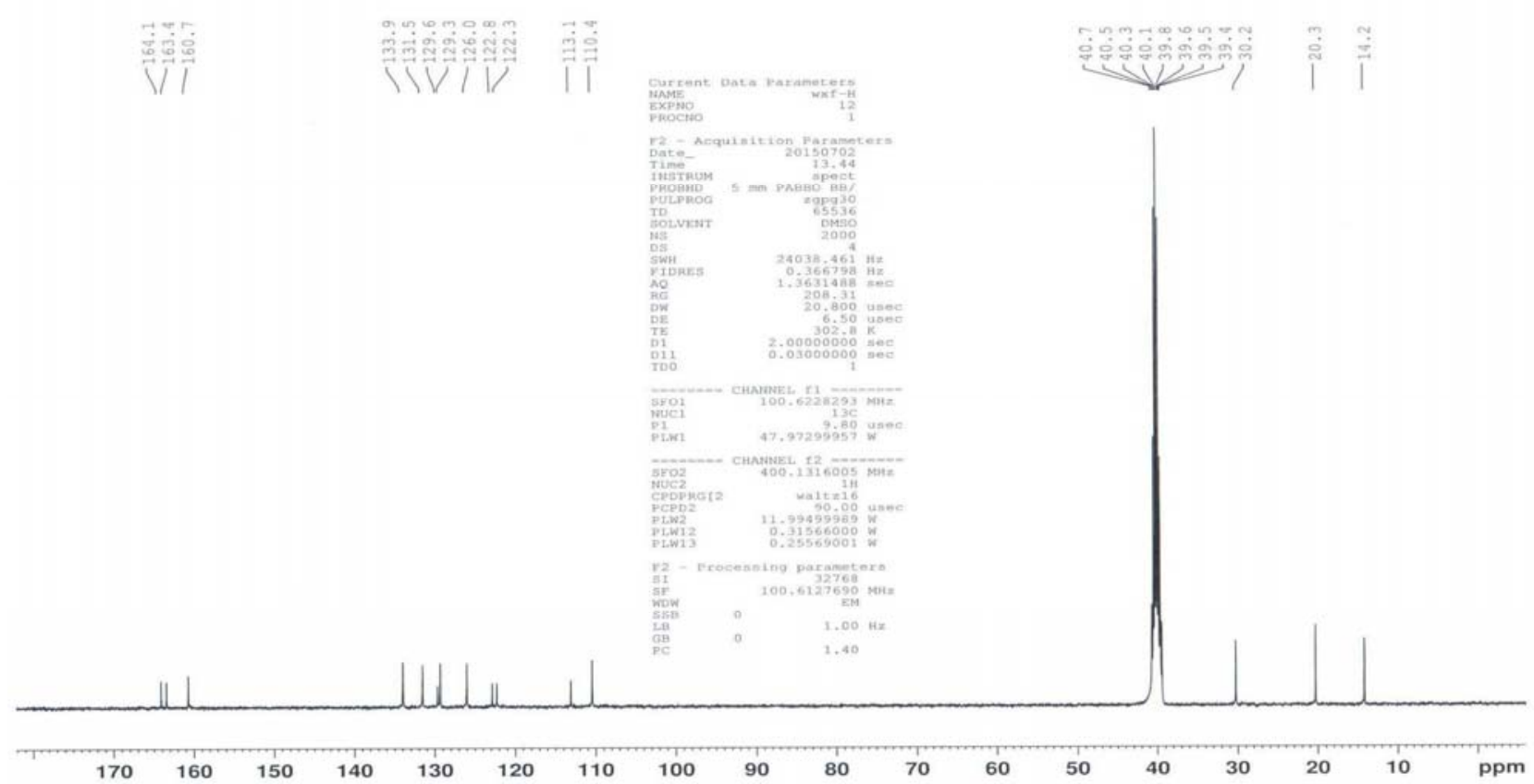

Figure S6. ${ }^{13} \mathrm{C}$ - NMR spectrum of NIOH $(100 \mathrm{MHz}, 298 \mathrm{~K}$, DMSO-d 6 ). 


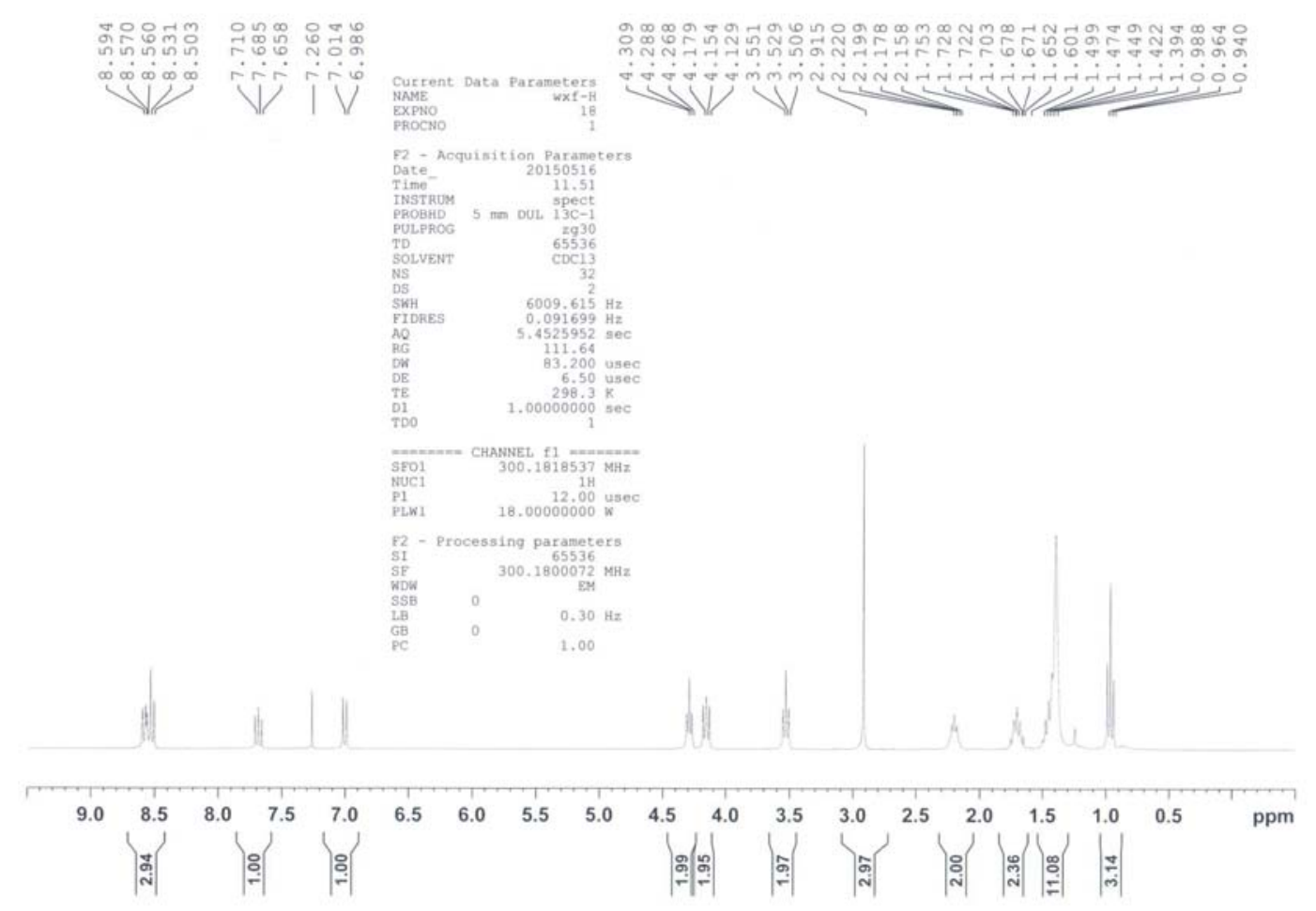

Figure S7. ${ }^{1} \mathrm{H}-\mathrm{NMR}$ spectrum of intermediate $1\left(300 \mathrm{MHz}, 298 \mathrm{~K}, \mathrm{CDCl}_{3}\right)$.

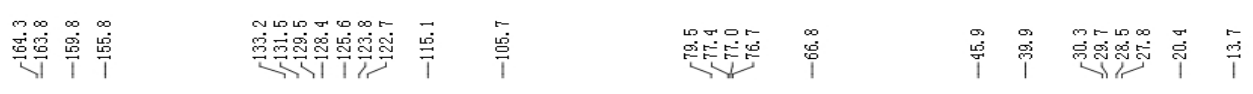

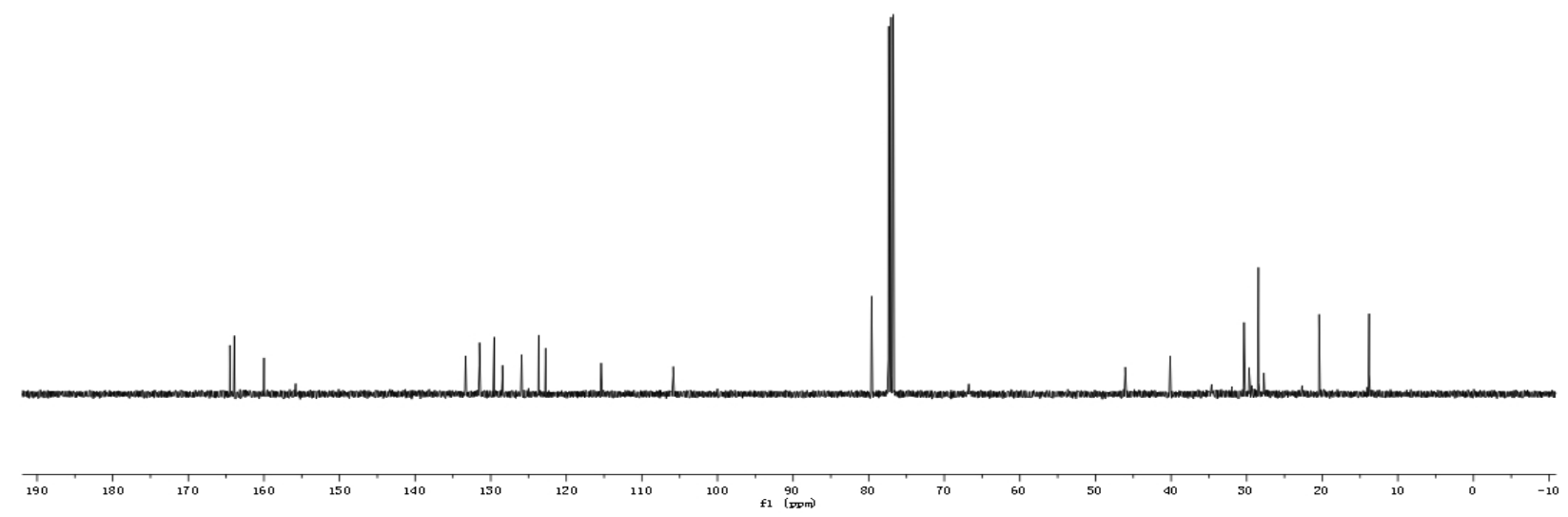

Figure S8. ${ }^{13} \mathrm{C}$-NMR spectrum of intermediate $\mathbf{1}\left(100 \mathrm{MHz}, 298 \mathrm{~K}, \mathrm{CDCl}_{3}\right)$. 


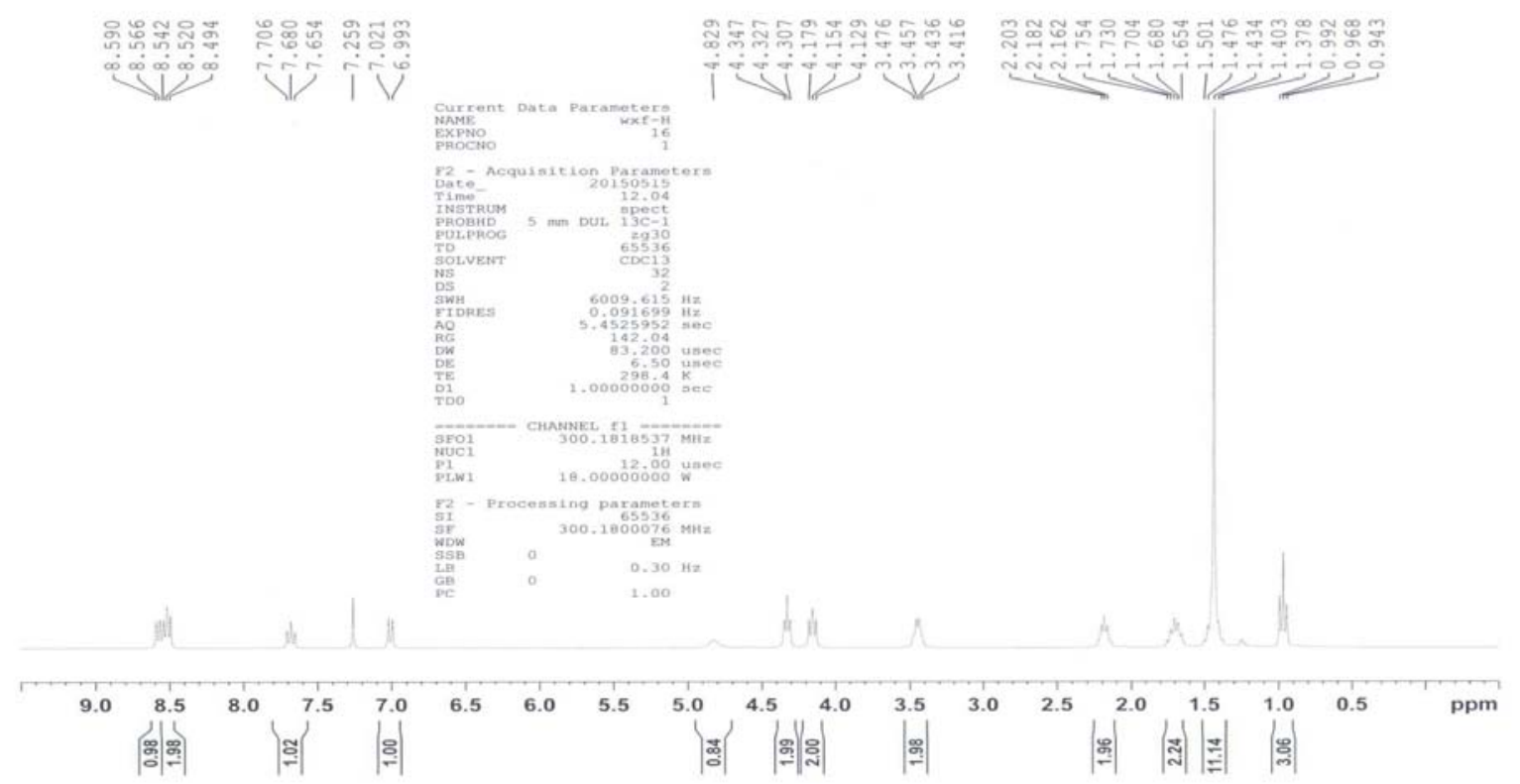

Figure S9. ${ }^{1} \mathrm{H}$-NMR spectrum of intermediate $2\left(300 \mathrm{MHz}, 298 \mathrm{~K}, \mathrm{CDCl}_{3}\right)$.
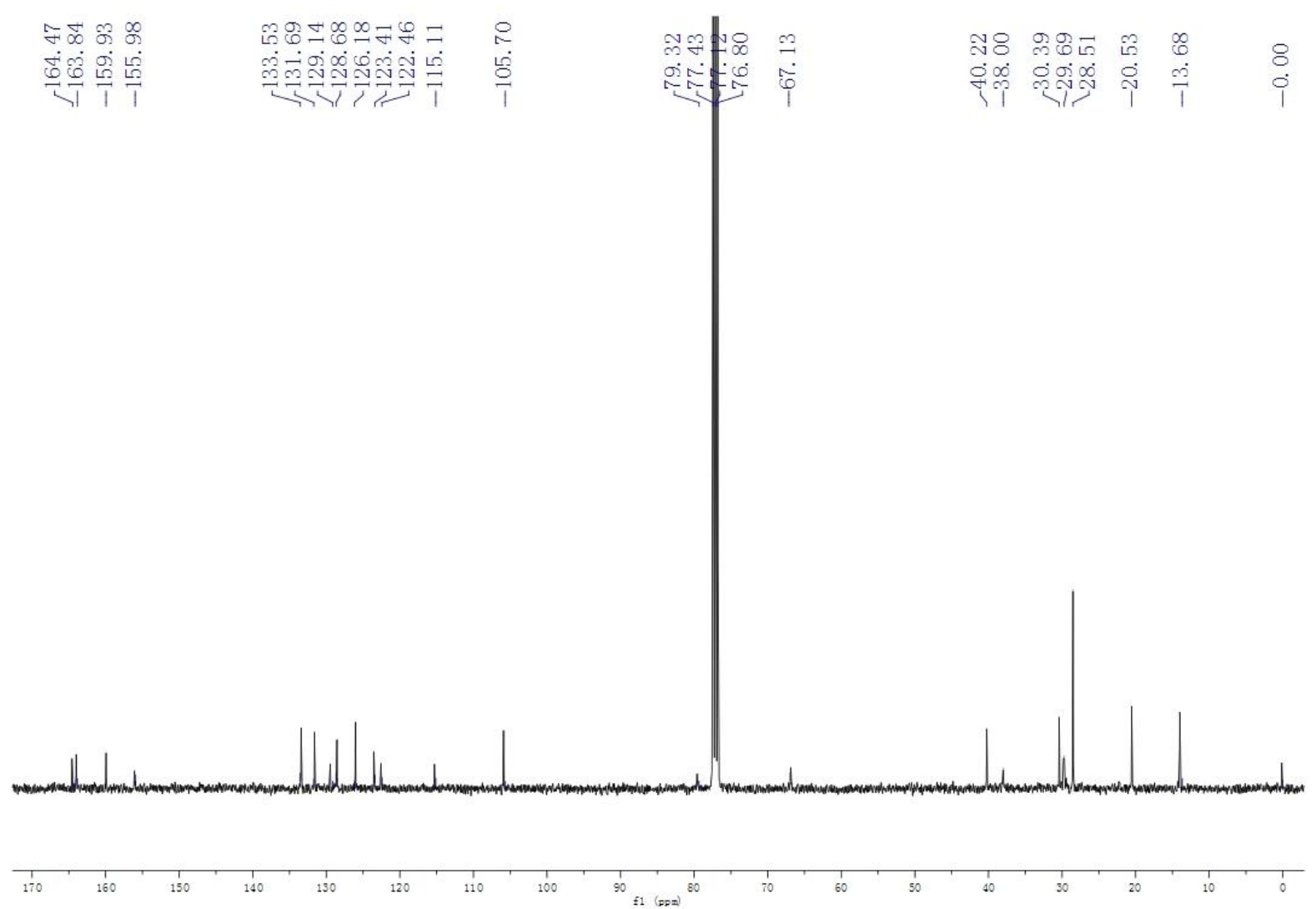

Figure S10. ${ }^{13} \mathrm{C}-\mathrm{NMR}$ spectrum of intermediate $2\left(100 \mathrm{MHz}, 298 \mathrm{~K}, \mathrm{CDCl}_{3}\right)$. 


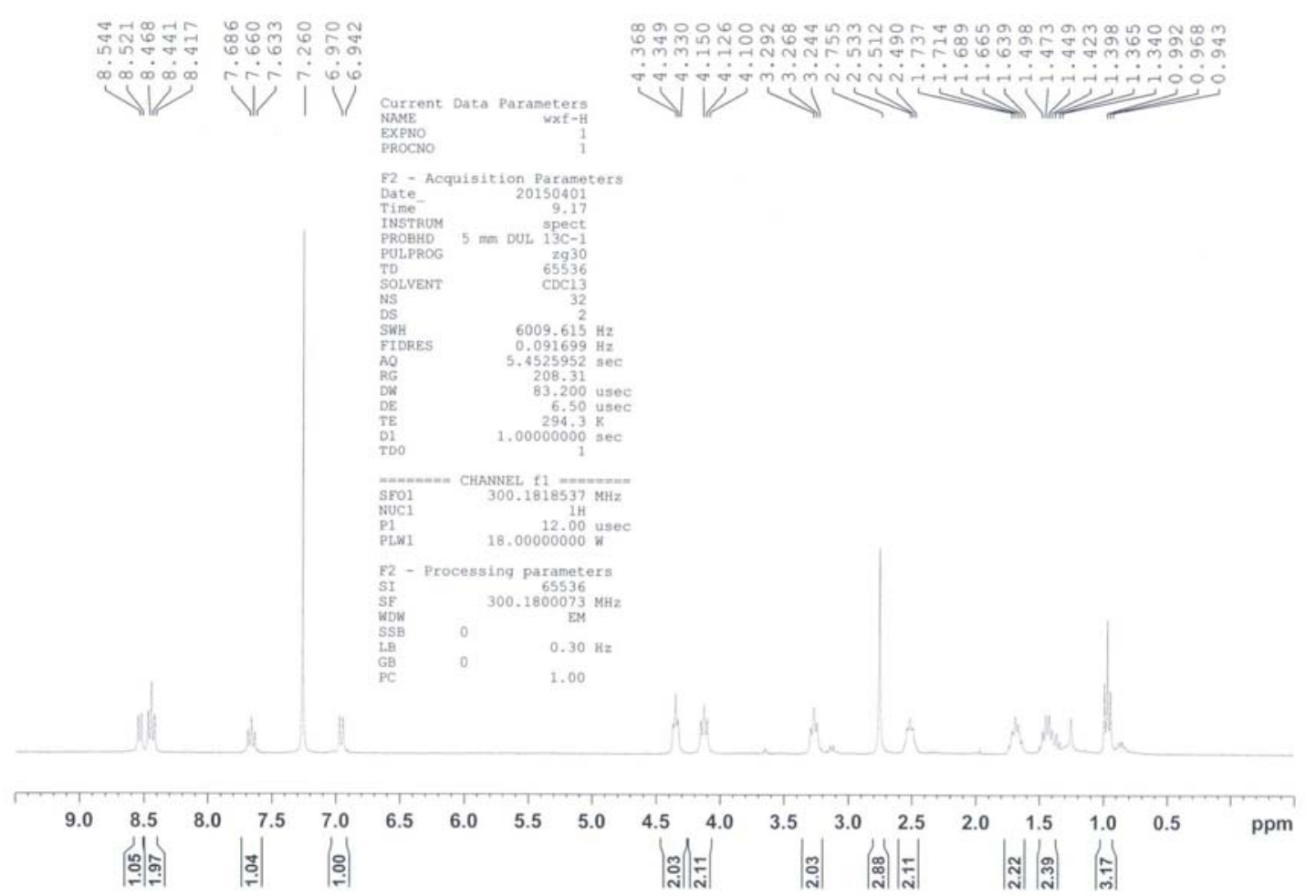

Figure S11. ${ }^{1} \mathrm{H}-\mathrm{NMR}$ spectrum of probe $1\left(300 \mathrm{MHz}, 298 \mathrm{~K}, \mathrm{CDCl}_{3}\right)$.

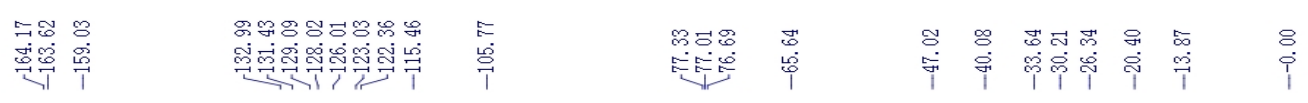

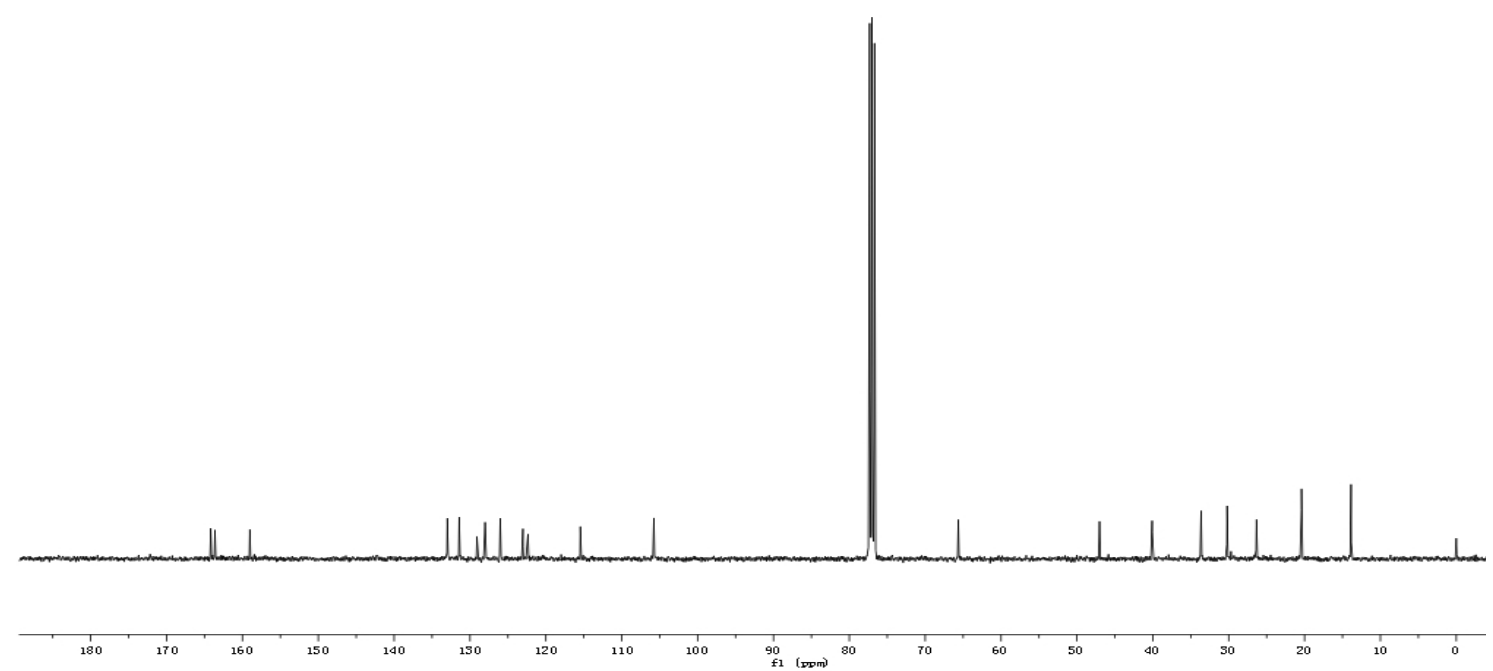

Figure S12. ${ }^{13} \mathrm{C}-\mathrm{NMR}$ spectrum of probe $\mathbf{1}\left(100 \mathrm{MHz}, 298 \mathrm{~K}, \mathrm{CDCl}_{3}\right)$. 


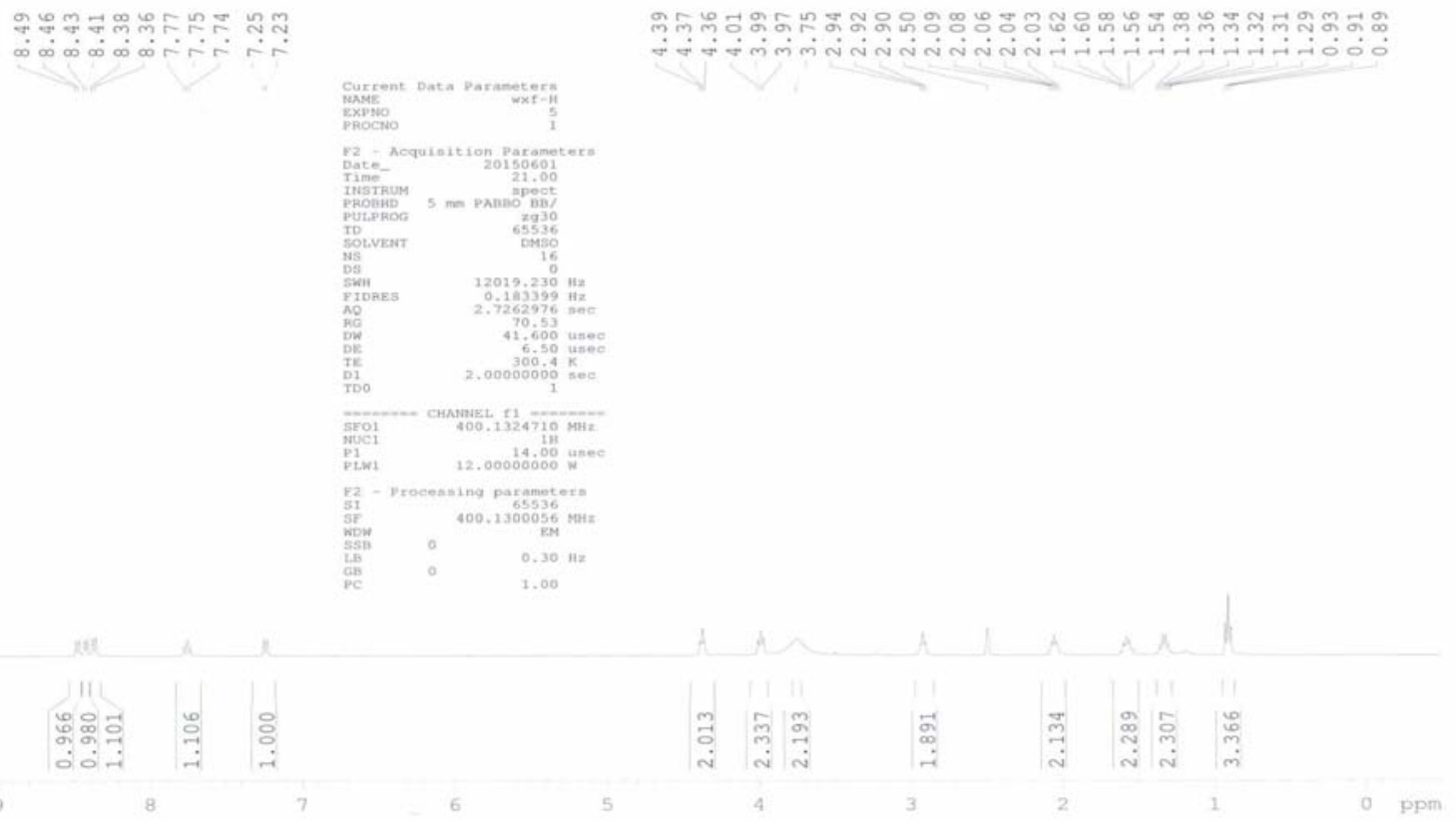

Figure S13. ${ }^{1} \mathrm{H}-\mathrm{NMR}$ spectrum of probe $2(400 \mathrm{MHz}, 298 \mathrm{~K}$, DMSO-d 6 ).

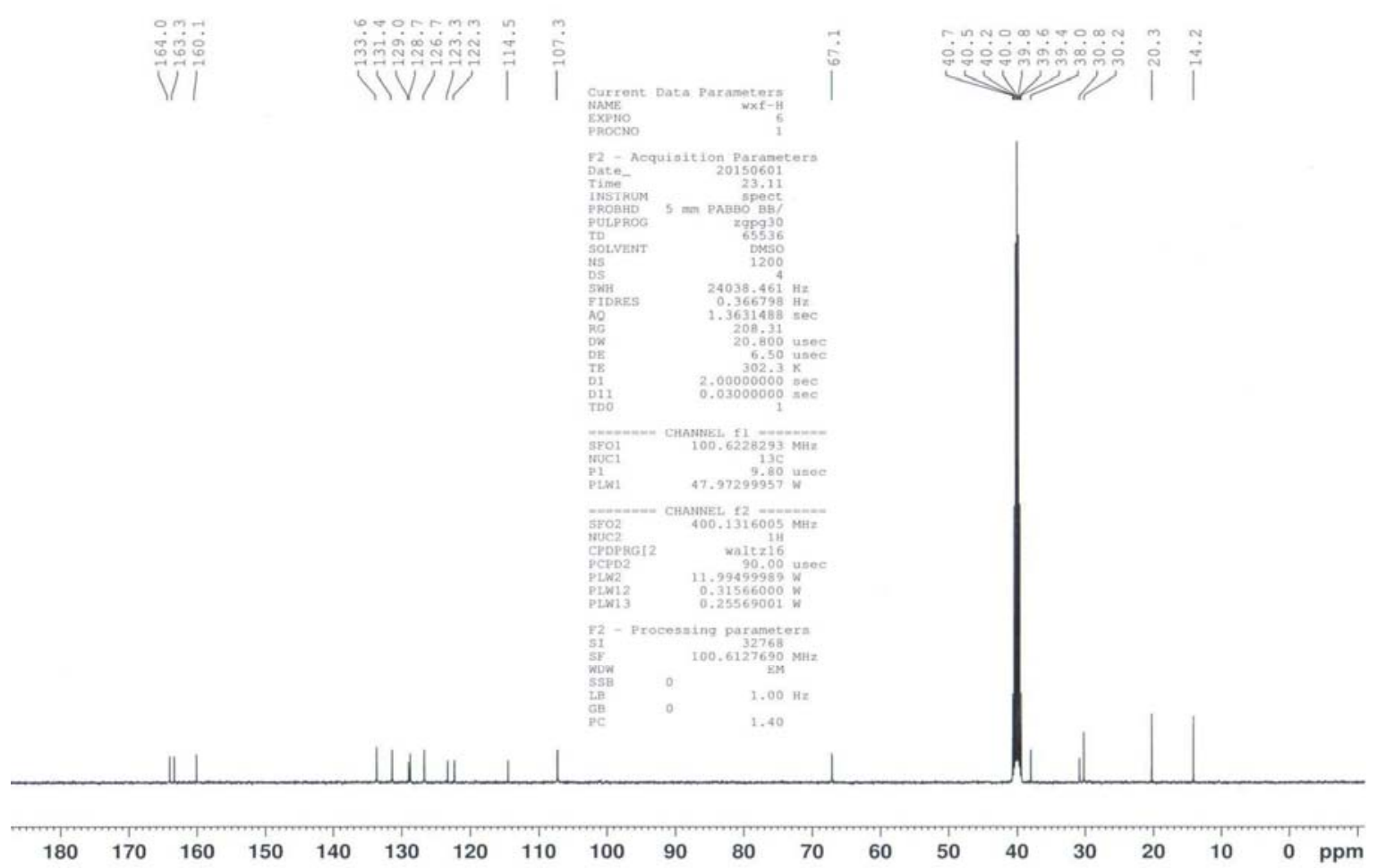

Figure S14. ${ }^{13} \mathrm{C}-\mathrm{NMR}$ spectrum of probe $2\left(100 \mathrm{MHz}, 298 \mathrm{~K}\right.$, DMSO-d $\left.{ }_{6}\right)$. 

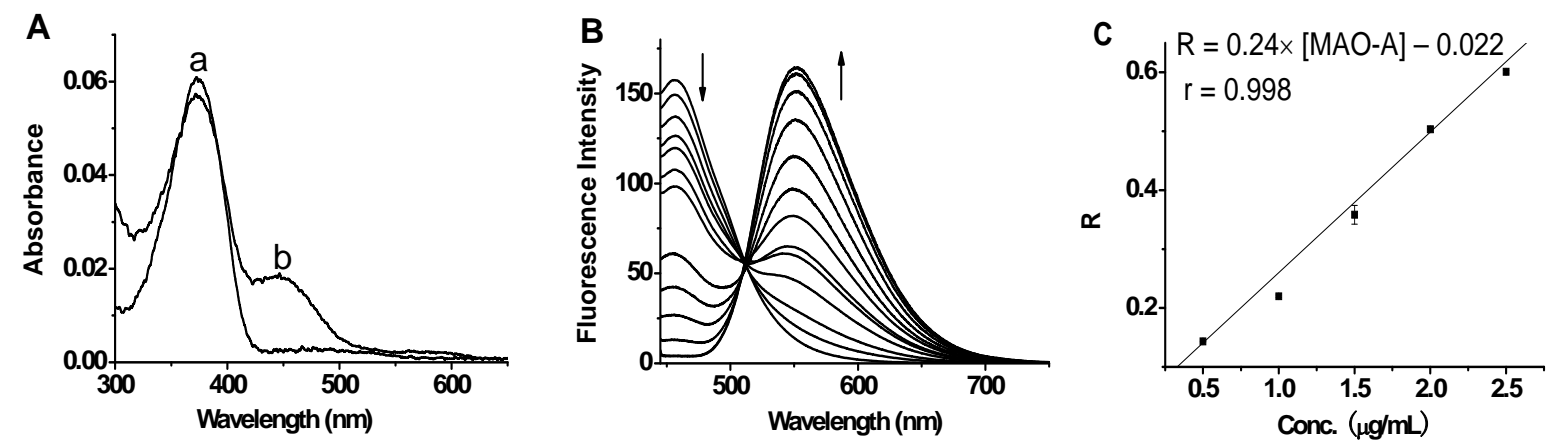

Figure S15. (A) Absorption spectra of probe $2(10 \mu \mathrm{M})$ before (a) and after (b) reaction with MAO-A $(2 \mu \mathrm{g} / \mathrm{mL})$ at $37{ }^{\circ} \mathrm{C}$ for $4.5 \mathrm{~h}$ in PBS (pH 7.4). (B) Fluorescence response of probe 2 (10 $\mu \mathrm{M})$ to MAO-A at different concentrations $(0,0.5,1.0,1.5,2.0,2.5,3.0,5.0,6.0,7.0,8.0,10$, and $20 \mu \mathrm{g} / \mathrm{mL})$. (C) The linear fitting curve between the fluorescence intensity ratio $\left(\mathrm{R}=\mathrm{I}_{550} / \mathrm{I}_{454}\right)$ and the concentration of MAO-A. $\lambda_{\mathrm{ex}}=425 \mathrm{~nm}$.

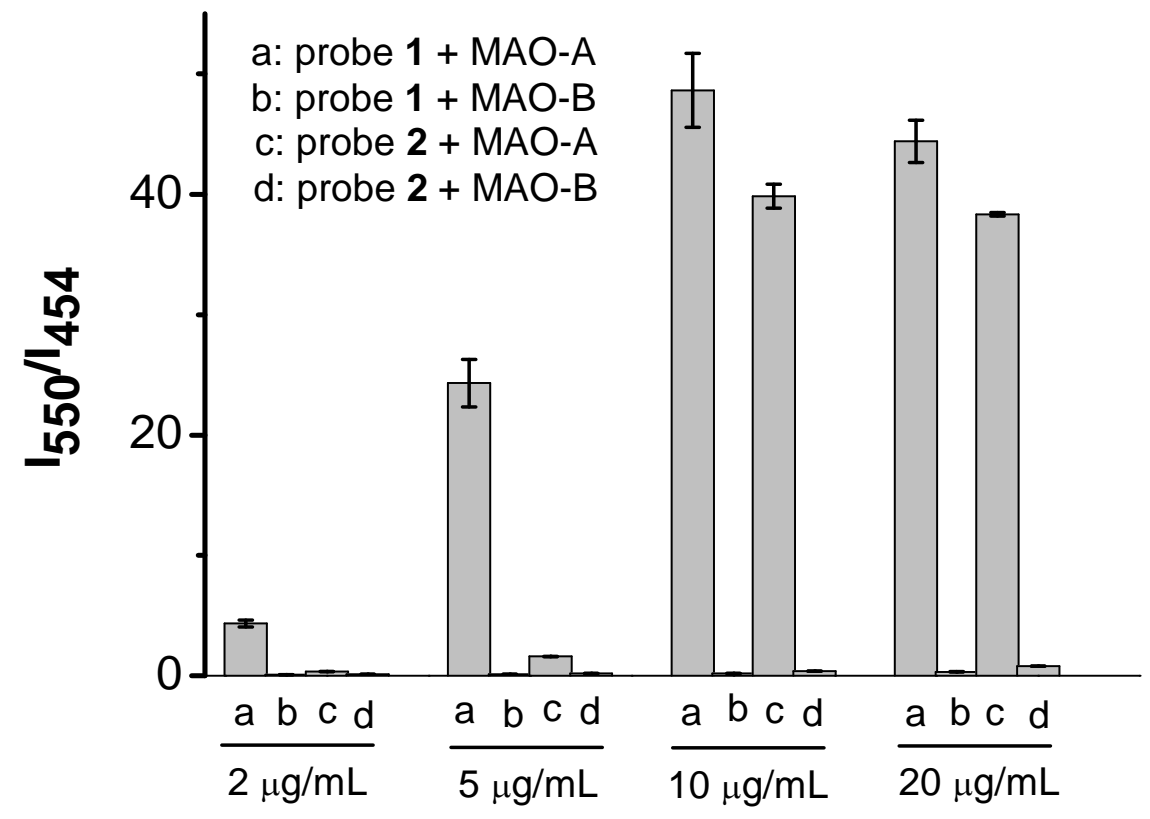

Figure S16. The ratio changes of fluorescence intensity of probe $1(10 \mu \mathrm{M})$ and probe $2(10 \mu \mathrm{M})$ upon reaction with MAO-A and MAO-B at varied concentrations $(2,5,10$ and $20 \mu \mathrm{g} / \mathrm{mL})$ for $4.5 \mathrm{~h}$. $\lambda_{\mathrm{ex}}=425 \mathrm{~nm}$. 
A

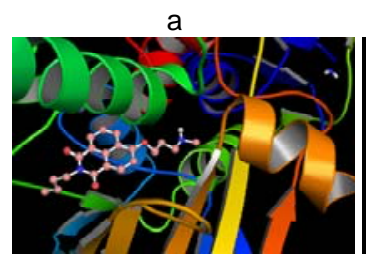

B

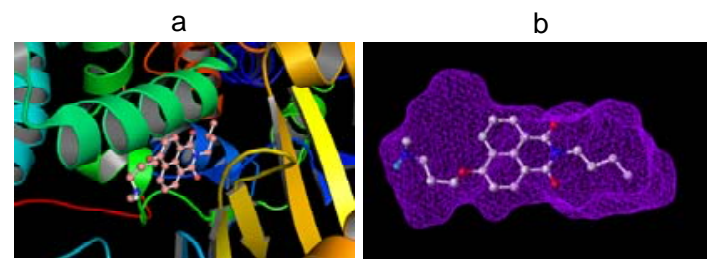

b

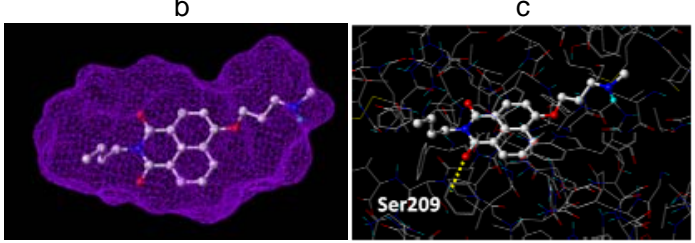

sects

Figure S17. Docking studies on probe 1 with (A) MAO-A and (B) MAO-B. (a) The docked conformer of probe $\mathbf{1}$ at the binding cleft of MAO (generated via Surflex docking-scoring combinations); (b) active pocket of probe 1 with MAO; (c) the details of the binding of probe 1 to MAO-A domains showing a potential hydrogen bond (yellow dotted line).
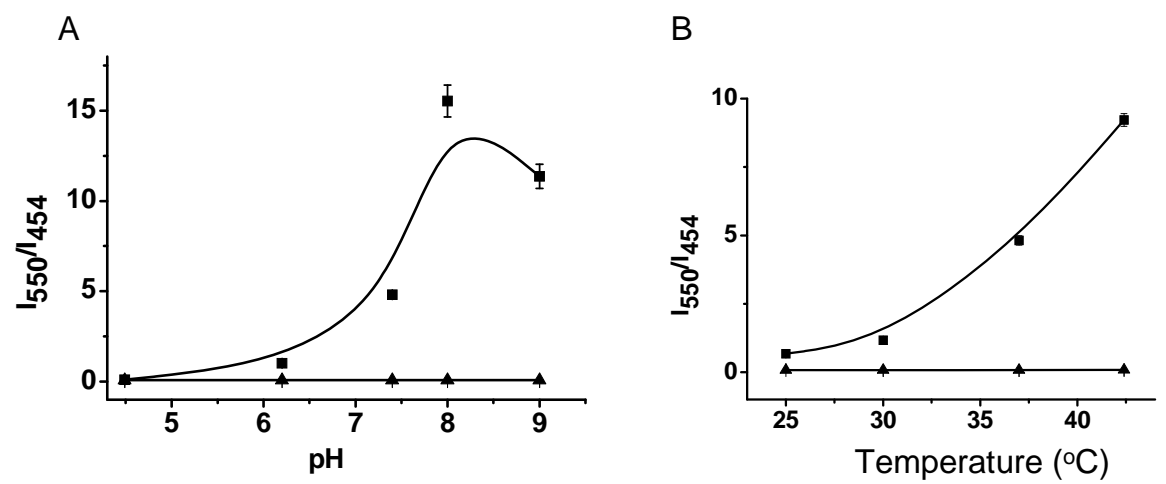

Figure S18. Effects of (A) $\mathrm{pH}$ and (B) temperature on the fluorescence intensity ratio of probe $\mathbf{1}$ $(10 \mu \mathrm{M})$ with $(\mathbf{\square})$ and without $(\boldsymbol{\Delta})$ MAO-A $(2 \mu \mathrm{g} / \mathrm{mL})$. The results are expressed as the mean \pm standard deviation of three separate measurements. $\lambda_{\mathrm{ex}}=425 \mathrm{~nm}$.

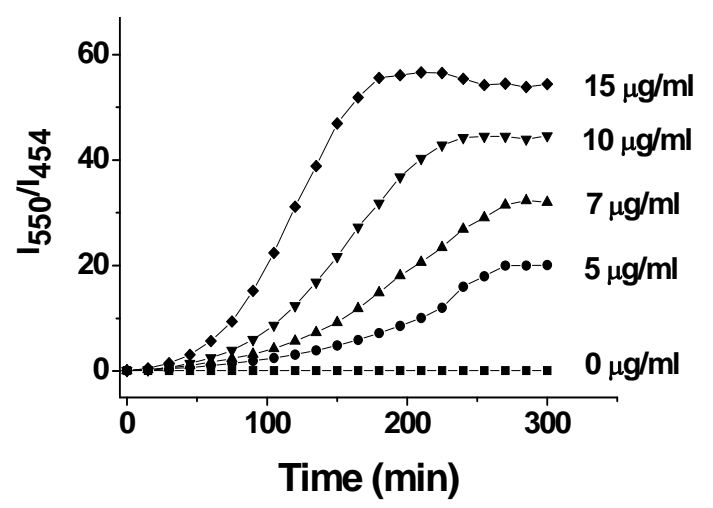

Figure S19. Plots of fluorescence intensity ratio $v s$. the reaction time of probe $1(10 \mu \mathrm{M})$ with varied concentrations of MAO-A $(0-15 \mu \mathrm{g} / \mathrm{mL})$. The measurements were performed at $37^{\circ} \mathrm{C}$ in PBS (pH 7.4) with $\lambda_{\mathrm{ex}}=425 \mathrm{~nm}$. 


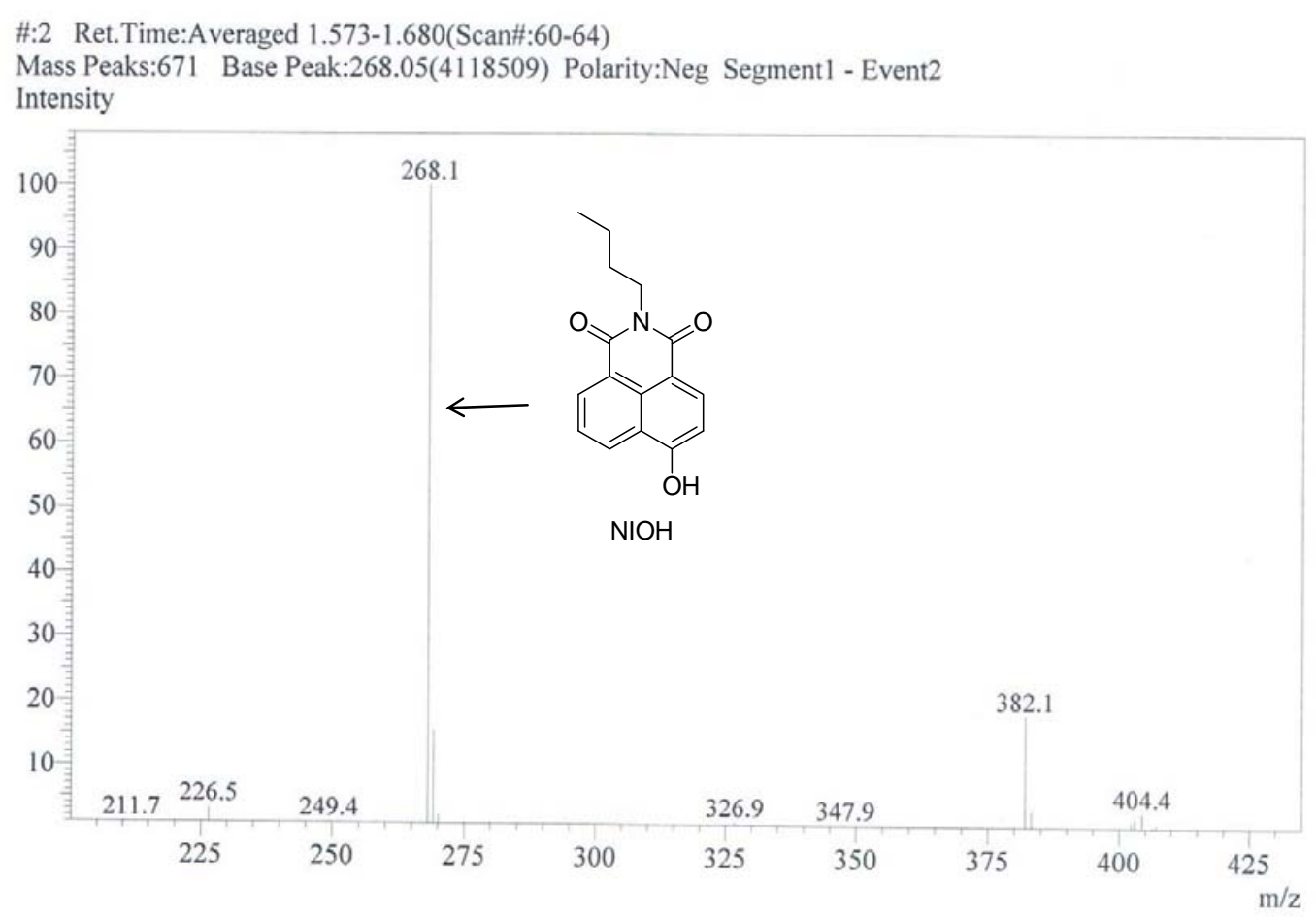

Figure S20. ESI mass spectrum of the reaction solution of probe $1(50 \mu \mathrm{M})$ with MAO-A $(5$ $\mu \mathrm{g} / \mathrm{mL}$ ). The peak at $m / z=268.1$ reflects the generation of $\mathrm{NIOH}$.

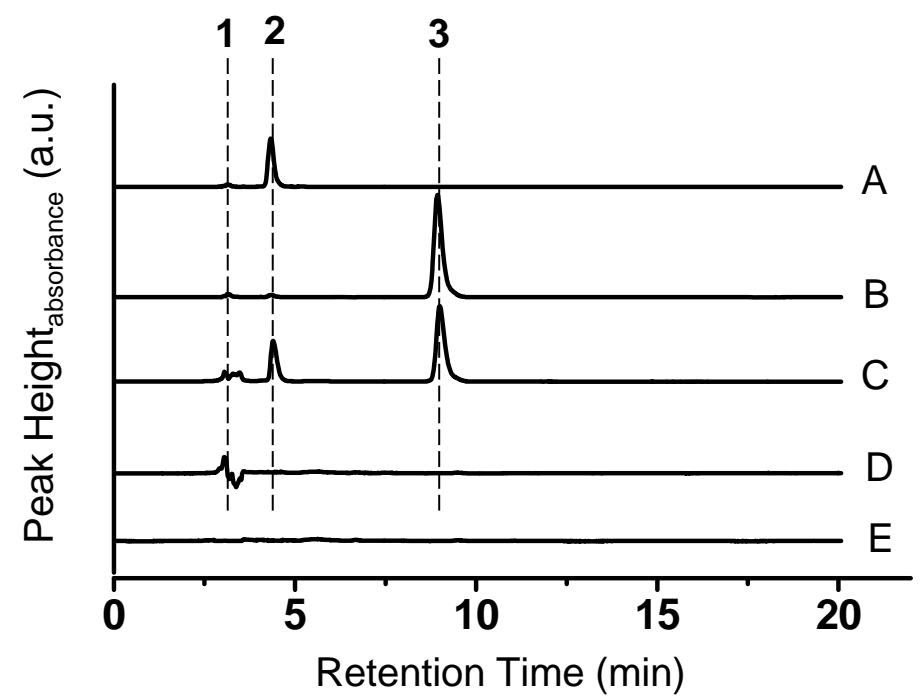

Figure S21. Chromatograms of different reaction systems. (A) probe $1(50 \mu \mathrm{M})$; (B) NIOH (5 $\mu \mathrm{g} / \mathrm{mL})$; (C) the solution of probe $1(50 \mu \mathrm{M})$ reacting with $5 \mu \mathrm{g} / \mathrm{mL}$ MAO-A for $2 \mathrm{~h}$; (D) MAO-A (5 $\mu \mathrm{g} / \mathrm{mL}$ ); (E) PBS (blank). The assignments of the peaks: (1) $3.02 \mathrm{~min}$, MAO-A; (2) $4.38 \mathrm{~min}$, probe 1; (3) $8.98 \mathrm{~min}, \mathrm{NIOH}$. The peaks eluting from the column were monitored at $254 \mathrm{~nm}$. 


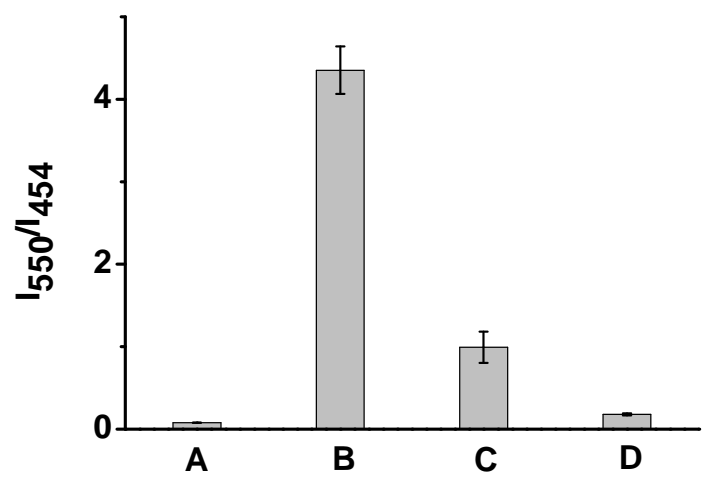

Figure S22. Fluorescence intensity ratios from different reaction systems. (A): Control $(10 \mu \mathrm{M}$ probe 1 in PBS of pH 7.4); (B): system (A) + MAO-A (2 $\mu \mathrm{g} / \mathrm{mL})$; (C): system (B) + clorgyline (1 $\mathrm{nM})$; (D): system (B) + clorgyline $(10 \mathrm{nM}) . \lambda_{\mathrm{ex}}=425 \mathrm{~nm}$.

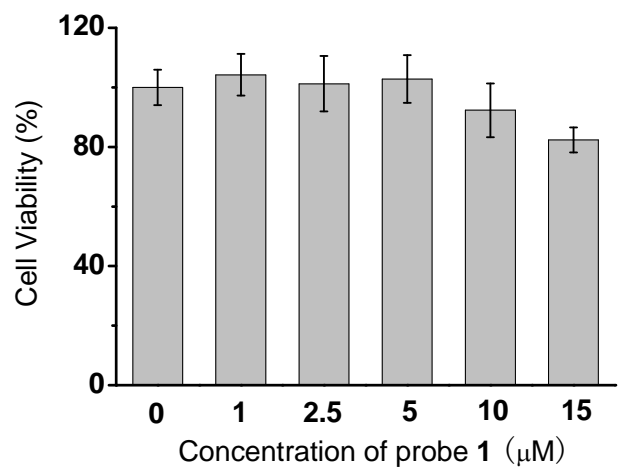

Figure S23. Effects of probe 1 at varied concentrations $(1-15 \mu \mathrm{M})$ on the viability of HeLa cells. The viability of the cells without probe $\mathbf{1}$ is defined as $100 \%$. The results are expressed as the mean \pm standard deviation of five separate measurements.

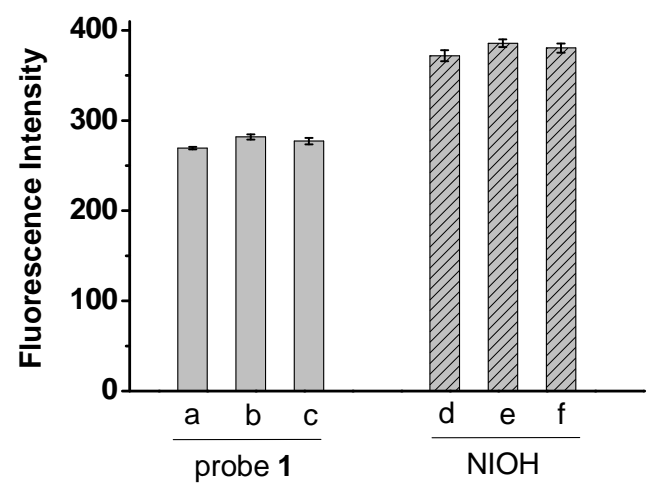

Figure S24. Effects of clorgyline and pargyline on the fluorescence intensity of probe 1 at $\lambda_{\mathrm{ex} / \mathrm{em}}=$ $425 / 454 \mathrm{~nm}$ and $\mathrm{NIOH}$ at $\lambda_{\mathrm{ex} / \mathrm{em}}=425 / 550 \mathrm{~nm}$, respectively. (a): probe $1(10 \mu \mathrm{M})$; b: probe $1(10$ $\mu \mathrm{M})+$ clorgyline $(40 \mu \mathrm{M})$; c: probe $1(10 \mu \mathrm{M})+$ pargyline $(40 \mu \mathrm{M})$; d: NIOH $(10 \mu \mathrm{M}) ;$ e: NIOH $(10 \mu \mathrm{M})+$ clorgyline $(40 \mu \mathrm{M}) ; \mathrm{f}: \mathrm{NIOH}(10 \mu \mathrm{M})+$ pargyline $(40 \mu \mathrm{M})$. The results are expressed as the mean \pm standard deviation of three separate measurements. 